LEATHER COMPANY
LEAMAN - MANAGER IN AN EFFICIENT AND INNOVATIVE
PÉREZ FRANCÉS ${ }^{4}$, MALGORZATA SIKORSKA ${ }^{5}$, DESIREE SCALIA ${ }^{6}$, CARLOS VAZ DE
CARVALHO ${ }^{7}$, VIORICA DESELNICU ${ }^{1}$
${ }^{1}$ INCDTP-Division Leather and Footwear Research Institute, Bucharest, Romania
${ }^{2}$ Centro Tecnológico das Indústrias do Couro, Portugal
${ }^{3}$ Creative Thinking Development, Greece
${ }^{5}$ FRP - Fundacja Rozwoju Przedsiebiorczosci, Poland
${ }^{6}$ Centro Italiano Per L'Apprendimento Permanente, Italy
${ }^{7}$ Virtual Campus, Portugal

\begin{abstract}
The leather industry, as a global industry, being highly dependent on access to raw materials and to export markets, is in a quickly changing business environment, which is particularly challenging for SME-dominated sectors, as are the leather and leather related ones. In order to remain competitive, businesses must be able to adapt to changes. Shortage of raw materials, the globalisation of production, environmental reasons, and the change of the profile of the leather industry outside EU, have caused a consequent change in the model for the leather production in Europe. However, Europe remains the leader in fashion, design and quality, as well as in leather science and technological innovation. There are opportunities in new technologies and new, innovative materials as well as in exports also as the demand in emerging markets is growing. Within that context, the necessary qualification requirements for working in the European leather industry must be redefined in order for the labour market to be reinvigorated with skilled professionals that will offer their full potential to the industry. Consequently, there is a need to restructure the leather production model across Europe towards an innovation and export oriented mentality. This change would require the leather manger to possess more and transverse skills, both technological and non-technological. Subsequently, the industry must better anticipate and manage change, and adapt to the future skills requirements. The paper presents the LEAMAN project aims and main outcomes that will result in better qualified professionals in the European leather and leather associated industries and promote both lifelong learning and equal opportunities in the knowledge-based society.
\end{abstract}

Keywords: managerial skills, innovative leather company

\title{
INTRODUCTION
}

The leather industry, as a global industry, being highly dependent on access to raw materials and to export markets, is in a quickly changing business environment, which is particularly challenging for SME-dominated sectors, as are the leather and leather related ones. In order to remain competitive, businesses must be able to adapt to changes. Shortage of raw materials, the globalisation of production, environmental reasons, and the change of the profile of the leather industry outside EU, have caused a consequent change in the model for the leather production in Europe.

However, Europe remains the leader in fashion, design and quality, as well as in leather science and technological innovation. There are opportunities in new technologies and new, innovative materials as well as in exports also as the demand in emerging markets is growing. 
Within that context, the necessary qualification requirements for working in the European leather industry must be redefined in order for the labour market to be reinvigorated with skilled professionals that will offer their full potential to the industry. Consequently, there is a need to restructure the leather production model across Europe towards an innovation and export oriented mentality. This change would require the leather manger to possess more and transverse skills, both technological and nontechnological. Subsequently, the industry must better anticipate and manage change, and adapt to the future skills requirements.

LEAMAN aims to create a framework that will result in better qualified professionals in the European leather and leather associated industries. Through the creation of a European Qualification Framework (EQF), with the use of ECVET scores, the project aims to promote both lifelong learning and equal opportunities in the knowledge-based society, as well as the further integration of the European labour market for all relevant professionals, such as existing and potential managers in the leather industry. LEAMAN addresses both technological and non-technological issues, from leather science to the application of new technologies, and from fundamental managerial skills, financial or project management skills, to issues regarding health and safety at the workplace, social responsibility or traceability in the leather value chain.

The partnership enroled in this project was established on the basis of combining the different backgrounds, experience \& expertise and comprises the following partners:

$\checkmark$ CTIC - Centro Tecnológico das Indústrias do Couro (Portugal) - Coordinator

$\checkmark$ CIAPE - Centro Italiano Per L'apprendimento Permanente (Italy)

$\checkmark$ CRE.THI.DEV (Greece)

$\checkmark$ FRP - Fundacja Rozwoju Przedsiebiorczosci (Poland)

$\checkmark \quad$ INCDTP - Division Leather \& Footwear Research Institute (Romania)

$\checkmark$ INESCOP - Instituto Tecnologico Del Calzado Y Conexas (Spain)

$\checkmark \quad$ VC - Virtual Campus (Portugal)

The main objective of LEAMAN project is to provide a set of instruments to re-engineer the leather industry and to offer to the existing and aspiring managers the most up-to-date information and knowledge tools.

This will be reached through the following specific objectives:

- A research report, based on desk and field research, depicting the state of the art for the leather and connected industries;

- A European Qualification Framework (EQF) of the New Manager for Efficient and Innovative Leather SMEs;

- The MOOC Being a manager in an Efficient and Innovative Leather Company: freely accessible and open licensed training platform dedicated to the improvement of knowledge and skills of managers and potential managers;

- A Virtual Challenge Community, a community made of relevant stakeholders active in the sector of leather and connected ones;

- A Decalogue of benefits deriving from the collaboration between companies, research and

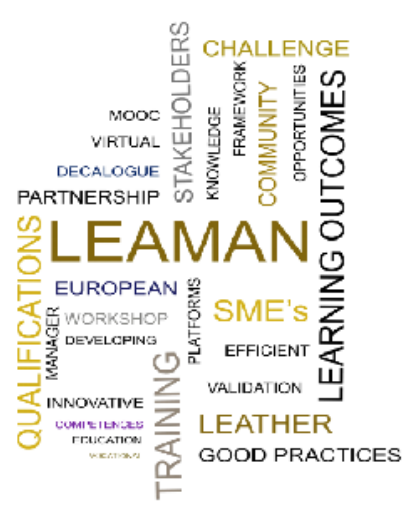
training centers. 
LEAMAN project aims to reach a large number of persons inside and outside the partnership, by maximizing the visibility of the project, promoting the projects' objectives and results, by creating a level of involvement of relevant stakeholders and ensuring that the project potential audience will be as large and relevant as possible. This was done by using different communications activities and channels (the training MOOC platform, social networks, newsletters, meetings, multiplier events, and the innovative leather product competition and crowd-funding campaign), by promoting the project and its results among European involved and/or interested organizations, and, at a national and regional/local level, by promoting the project results among target organisations and end-users.

The target groups of the project are:

$>$ VETs, policy-makers, associations and organisations dealing with leathers, universities, research centres dealing with the project topics, companies (both the leather and the connected ones) and trainers;

$>$ Managers of the leather industry and potential ones, managers of the leather connected industries and potential ones will be offered an up-to-date open access training course appropriate to their actual needs with technological and non-technological contents;

$>1500$ persons in total are expected to be impacted, by one way or another, by the project results, either by their participation in multiplier events (6 Multiplier Events are envisaged - one in each participating country), learning labs and validation workshops or by registering to the Virtual Challenge Community, by using the EQF, by visiting and testing the MOOC and the platform, by getting informed by the newsletter and by participating in the innovative leather products competition.

\section{ACTIVITIES AND RESULTS}

A comprehensive Analysis of State of the art and the Training Needs of the sector, identified by the managers and VET providers from participating countries.

$\checkmark$ The first part - State of the art, based on a desk research;

$\checkmark \quad$ The second part - The field Survey Analysis implemented using 2 different questionnaires that were defined based on the desk research results and designed according to standard research methodology:

- Questionnaire for Managers and Potential Managers - 31 questions - 123 respondents

- Questionnaire for Experts\&VET professionals - 22 questions - 70 respondents

Based on the research report, an European Qualification Framework (EQF) of the New Manager for Efficient and Innovative leather SMEs, was produced in order to serve as a reference tool to compare the qualification levels of the different qualifications systems and will be constructed around existing EQF at national levels, inputs, addressing knowledge, skills and competences, organised in learning outcomes.
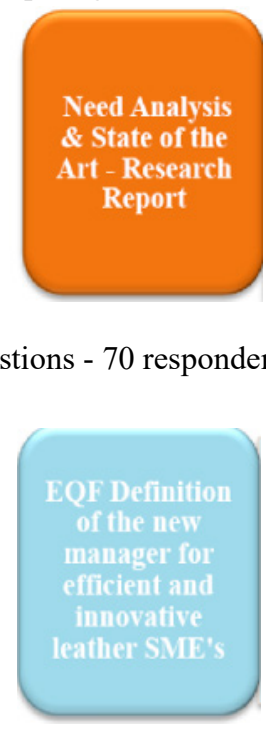
The methodology for development of the Training Programme:

- Definition of the units of learning outcomes;

- Establishing of ECVET points;

- Assessment of learning outcomes.

The steps of the developing process are presented in the following chart:

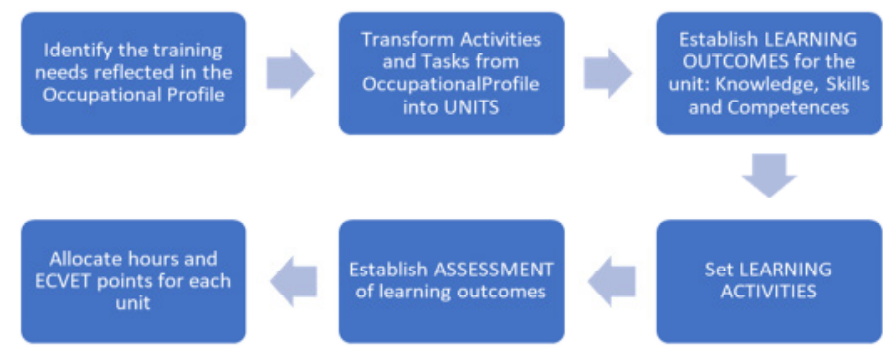

The Activities and Tasks from the occupational profile have been transformed into the following Units of the Training Programme:

Unit 1. Human resources and innovation management

Unit 2. Business management and internationalization

Unit 3. Tanning processes development

Unit 4. Standardization and Quality Control

Unit 5. Environmental impact of the tanning industry

Unit 6. Health and Safety at Work (HSW) at tanning company

Each Unit has a main Objective and the EQF definition has been established by transforming the Knowledge, Skills, autonomy and responsibility from the previous Occupational Profile.

\begin{tabular}{|c|c|c|}
\hline \multicolumn{3}{|c|}{ Training units, hours, ECVET points } \\
\hline \multirow[b]{2}{*}{ UNIT } & \multicolumn{2}{|c|}{ EQF 5} \\
\hline & Hours & ECVET points \\
\hline Unit 1. Human resources and innovation management & 140 & 8 \\
\hline Unit 2. Business management and internationalization & 280 & 16 \\
\hline Unit 3. Tanning processes development & 240 & 16 \\
\hline Unit 4. Standardization and Quality Control & 140 & 8 \\
\hline Unit 5. Environmental impact of the tanning industry & 140 & 8 \\
\hline $\begin{array}{l}\text { Unit } 6 . \text { Health and Safety at Work (HSW) at tanning } \\
\text { company }\end{array}$ & 60 & 4 \\
\hline $\begin{array}{ll} & \text { TOTAI }\end{array}$ & 1000 & 60 \\
\hline
\end{tabular}

According to the results of the field survey, the content of the training material and the MOOC (Massive Open Online Courses) "Being a manager in an Efficient and Innovative leather company" was produced, being focused on specific knowledge and skills for actual managers and potential ones of leather industries and connected fields. The MOOC will be freely accessible and open licensed.

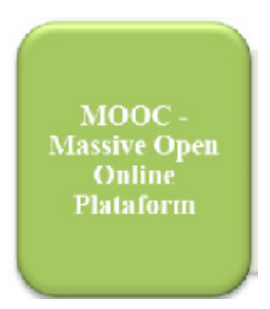


The MOOC has the following structure (7 Units $\mathrm{x} 4$ Lessons):

1: Business Management

2: Innovation management

3: Leather processes development

4: Standardization and Quality Control

5: Environmental impact of the tanning industries

6: Health and Safety at Work

7: Personal and transversal skills

The Virtual Challenge Community - another result - is integrated by relevant stakeholders active in the sector of leather and connected ones and aims to facilitate the exchange of information, knowledge and experience. It also served as a platform for the innovative leather products competition that will, till the end of the project, lead to the launch of a crowd funding campaign for the winners of the competition for the most innovative leather products.

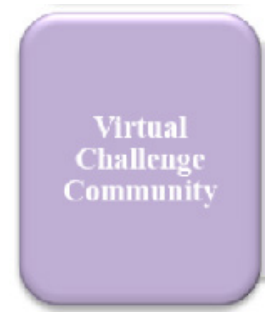

\section{Leaman Competition}

The purpose of the Competition was to promote innovative leather products, services, solutions or technologies and inspire interested stakeholders' creativity.

Participants to the competition were asked to share ideas and brainstorm for creating innovative leather products. The ideas of innovative leather products were voted online. The Competition was opened for all interested stakeholders from partners countries: Greece, Italy, Poland, Portugal, Romania and Spain. Participants were required to submit their submissions based on the application forms (stage 1) via the Virtual Challenge Community platform and prepare business plans (stage 2) and presentations on VCC platform and on partners websites (stage 3) before the date of 15.06 .2018 for submission online. Stage 4 included online voting for the best ideas and took place between 1630.06.2018. Three projects with the highest score were awarded.

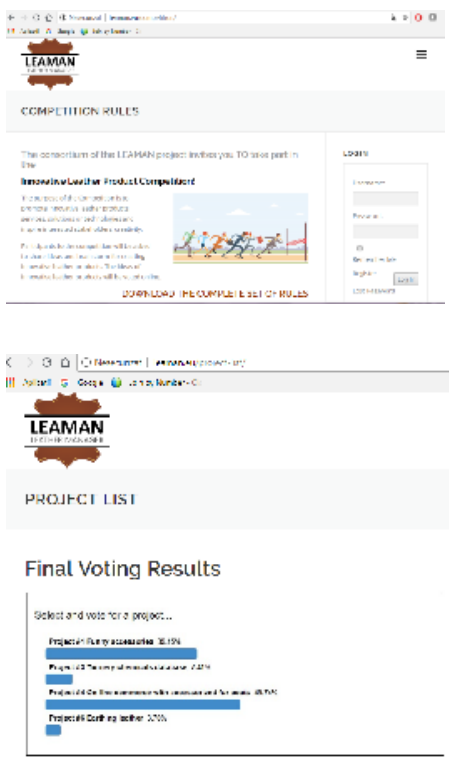

Stage 5 concerned announcement of the results at the meeting in Poland on 5.07.2018 and on partners websites and VCC platform. In stage 6 three of the best projects will be submitted to Indiegogo.com platform for crowdfunding - this stage is in developing now.

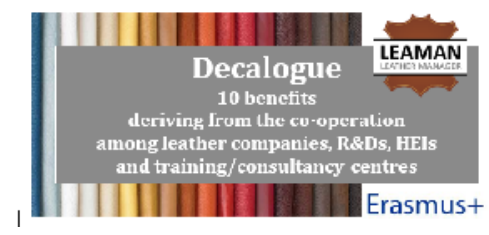


Furthermore, the virtual community will host the Decalogue of benefits deriving from the collaboration between companies, research and training centres in developing innovative leather products.

\section{CONCLUSIONS}

Results of desk and field research conducted in the first stage of LEAMAN project have shown that co-operation between SMEs and knowledge institutions (R\&Ds, HEIs) has been generally established on the basis of joint research and the provision of support services. Joint research is sought as an essential part of research institutions activities, SMEs are interested in co-operation to develop new materials and products. There is a variety of support services provided by HEIs, technology/research centres, training and consultancy institutions, VETs that leather companies are using or could use.

Co-operation among leather companies, R\&Ds, HEIs and training/consultancy centres offers a lot of benefits.

The list below highlights the top 10 motivations (Decalogue of benefits):

1. Approach to updated knowledge and innovative technologies

2. Optimise resources

3. Have access to funding opportunities

4. Know and develop new business management ideas for leather companies

5. Implement sustainability and environmental approach

6. Protect your IP and IPR

7. Ensure more safety and health at workplaces

8. Develop new markets and internationalization

9. Provide education and lifelong learning

10. Have multidisciplinary approach to complex problems

\section{REFERENCES}

www.leaman.eu

Acknowledgements

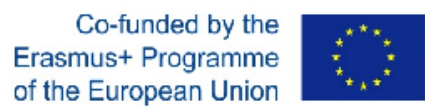

The LEAMAN project has received funding from the European Union's ERASMUS+ Program under the grant agreement number 2016-1-PT01-KA202022831 . 